\title{
EFEKTIVITAS PENGGUNAAN PEREKAT LALAT DAN UMPAN LALAT DALAM PENGENDALIAN LALAT RUMAH
}

\author{
Fajriansyah $^{1}$ \\ 1, Jurusan Kesehatan Lingkungan Politeknik Kesehatan Kemenkes RI Aceh Jln. Soekarno-Hatta, Lampeunerut. \\ Aceh Besar. Telp: 0651 46128. E-mail: fajri.ansyah@yahoo.co.id
}

\begin{abstract}
ABSTRAK
Upaya pembangunan kesehatan adalah pengendalian vektor terutama lalat rumah sebagai penyebab menularnya penyakit sehingga perlu diupaya pengendalian. Salah satu tindakan pengendalian lalat rumah dapat dengan menggunakan kertas perekat dan umpan lalat karena bahan tersebut mudah ditemukan dan mudah pemakaiannya. Metode penelitian adalah pra eksperimen berdesain The Static Group Comporation. Pengumpulan data dengan cara observasi dan pengukuran parameter. Analisis data yang digunakan adalah uji T-test. Hasil penelitian yang dilakukan dalam 3 kali replikasi adalah 168 ekor yang mati pada umpan lalat dan 64 ekor yang tertangkap pada perekat lalat, Hasil statistik mempunyai nilai p=0,000, maka terdapat perbedaan yang bermakna dalam penggunaan perekat lalat dan umpan lalat dalam pengendalian Musca domestica. Kesimpulan penelitian terdapat perbedaan dalam penggunaan perekat lalat dan umpan lalat dalam pengendalian Musca domestica, dimana umpan lalat ternyata lebih efektif.
\end{abstract}

Kata kunci : Perekat, Lalat, Pengendalian

\begin{abstract}
Health development efforts are primarily vector control houseflies as the cause of infectious diseases that need diupaya control. One house fly control measures can use adhesive paper and feed the flies because the material is easy to find and easy to use. The research method is pre experimental design The Static Group Comporation . The collection of data by observation and measurement parameters. Analysis of the data used is the $T$-test . Results of research conducted in three times replication is 168 tails that died on the bait flies and 64 tail caught on the adhesive flies, the results of statistic has a value of $p=0.000$, then there is a significant difference in the use of adhesive flies and lures the flies in the control of Musca domestica. Conclusions of research there are differences in the use of adhesive flies and lures the flies in the control of Musca domestica, which lures the flies proved to be more effective.
\end{abstract}

Keywords : Adhesives, Flies, Control 